İnceleme Makalesi - Review Article

\title{
İkinci Yılında
}

\section{Dava Şartı Arabuluculuk Alanında Gelişmeler ve Öneriler}

\section{Developments and Recommendation About Mediation in the Second Year}

Levent AKIN*

(iD) 0000-0002-7543-3164
Sosyal Güvenlik Dergisi / Journal of Social Security

Cilt: 10 Sayı: 1 Y1l: 2020 /Volume: 10 Issue: 1 Year: 2020

Sayfa Aralı̆̆1: 1-18 / Pages: 1-18

DOI: $10.32331 /$ sgd.752070

\section{ÖZ}

Türk hukuk sistemine 2012 yılında dâhil olan arabuluculuk kavramı, dava şartı arabuluculukla 2017 yılında karşılaştı. Geçen iki yıl sadece dava şartı niteliğinde bir milyonun üzerinde arabuluculuk görevlendirmesi yapıldı. Bu süreçte gerçekleştirilen arabuluculuk faaliyetlerinde, sistemin işleyişine ilişkin olumlu-olumsuz tespitler yapabilmek mümkün oldu. Halen arabuluculuk konusunda mevzuatı yenileme çalışmaları sürdürülüyor. $\mathrm{Bu}$ çalışmada, oluşturulacak yeni sistemde gözden geçirilmesinde yarar gördüğümüz kavramlara ve oluşturulmasının sisteme katkı sağlayacağını düşündüğümüz yeni yapılara yer vereceğiz.

Anahtar Sözcükler: Arabuluculuk, dava şartı arabuluculuk, arabuluculuk merkezleri, arabulucu yardımcılığı, arabuluculuk eğitimi, arabuluculuk stajı

\section{ABSTRACT}

Mediation began in Turkey in 2012. Mandatory mediation entered into force in Turkey in 2017. Over one million mediations done in the past two years. In this process, it was possible to determine the positive and negative aspects of mediation. It was seen that some concepts need to be renewed. It was understood that some concepts should be regulated by law. Therefore, two years of experience showed us the steps to be taken. This study aims to contribute to the new law study on mediation. Our proposed structure should take place in the new system to be established in Turkey reveals.

Keywords: Mediation, mandatory mediation, mediation center, mediation assistant

Önerilen atıf şekli: Akın, L. (2020). İkinci Yılında Dava Şartı Arabuluculuk Alanında Gelişmeler ve Öneriler. Sosyal Güvenlik Dergisi (Journal of Social Security). 10(1). 1-18. 


\section{GİRIŞ}

Arabuluculuk, tüm dünyada uygulanan klasik uyuşmazlık çözüm yöntemlerine bir alternatif olmaktan ziyade farklı bir bakış açısı getirme hedefiyle ortaya çıkmıştır. Ancak tıpkı bizim gibi, uygulandığı hemen her ülkede temel amacının, içinden çıkılamaz hale gelen yargının iş yükünü hafifletmek olduğu, bunu da mümkün olduğunca hızlı ve az maliyetle yapmaya çalışacağı belirtilmektedir. Bu yöntemde tarafların, bağımsız üçüncü bir kişi (arabulucu) yardımıyla kendi çözümlerine ulaşması sağlanmaya çalışılmaktadır (Tanrıver, 2011: 2 vd. Pekcanıtez, Atalay, Özekes, 2013: 1095 vd. Özbek, 2009: 205 vd. Goodman, 2004: 24).

Arabuluculuğun ülke gündemine girmesinden bugüne neredeyse 8 yıl geçmiş bulunuyor. (7.6.2012 tarih ve 6325 sayılı Kanun). Ancak arabuluculuğun asıl gündem oluşturmasına yol açan yasanın 12.10.2017 tarih ve 7036 sayılı İş Mahkemeleri Kanunu olduğu düşünülürse, dava şartı arabuluculuk sadece 2 yaşında.

Dava şartı arabuluculuk henüz başlangıç aşamasında, ülkemizde çok ciddi ses getirmiş ve günden oluşturmuş durumda. Hiçbir hukuki müesseseye kısmet olmayan bu durumun, bize neyi gösterdiğinin, konunun tüm taraflarınca çok ciddi analiz edilmesi gerektiği kanısındayız.

Bu çalışmamızda, yasanın yürürlüğe girmesinden sonra geçen iki yılın ardından, hem Adalet Bakanlığımız tarafından konuya ilişkin açıklanan başarılı hususlara hem de kişisel gözlemlerimizle tespit edebildiğimiz sorunlara ve bulabildiğimiz çözüm önerilerine yer vermeye çalışacağız.

\section{I- DAVA ŞARTI ARABULUCULUK ILE GÜNDEMIMIZE GIREN KAVRAMLAR}

Arabuluculuk iki yaşını dolduruncaya kadar hukuk yaşamına özgün kavramlar kazandırdı. Esasen çoğu yasal düzenlemelerde yer alamayan bu kavramlar, arabuluculuk uygulamalarının sonucu olarak görülebilir. Kavramlara verilen anlamları irdelendiğinde, uygulamanın olumlu ya da olumsuz olarak hangi noktada ve ne şekilde sürdüğünü anlayabilmek kolaylaşacaktır.

Uygulamada tespit edebildiğimiz ve hemen her arabulucuya çok şey ifade eden bu kavram ve terimlerin bazıları şunlardır: Uzlaşma kültürü, arabuluculuk mesleği, arabuluculukta taraf vekilliği, seri dosya, arabulucu başına düşen dosya sayısı, taraf sayısı, arabuluculuk merkezi, arabuluculuk şirketleri, işçi arabulucu, patron arabulucu, arabuluculuk şirketi yatırımcıları, harici anlaşma, kadrolu arabulucu, tarife altı arabuluculuk hizmeti, arabuluculuk anlaşma miktarının altında vergi beyanı, toplu arabuluculuk yoluyla ibra/feragat/ikale, irade fesadı, yok hükmünde arabuluculuk faaliyeti, zorunlu görünümlü ihtiyari arabuluculuk, temel eğitim/ uzmanlık eğitimi/ yenileme eğitimi/ eğiticilerin eğitimi, arabuluculuk anlaşma belgesinin iptali, arabuluculuk sinavi ve sinavdan muafiyet, arabuluculukta kota, arabuluculuk görevinde tevkil, whatsapp grupları, telekonferans, ...vs.

\section{II- MEVZUAT OLUŞTURMA/YENILEME SÜRECI}

Gelişen sosyal ilişkiler, ekonomik yapı, ihtiyaç ve beklentiler ile teknoloji, her alanı olduğu gibi hukuku da etkiliyor. Bu da doğal olarak yasaların yenilenmesi ihtiyacını doğuruyor. Arabuluculuk kurumu da dinamizmi yüksek bir alan olduğu için bu beklentilerden kendine düşen payı alıyor.

İlk arabuluculuk yasamızın yürürlüğe girişinden bugüne kadar sekiz yıl, dava şartı arabuluculuğun hayat geçmesinden itibaren ise iki yıl geçti. $\mathrm{Bu}$ süreçte ülkemizdeki gelişmelere, bir de arabuluculuk konusunda yaşananlar eklendiğinde, doğal olarak mevcut 
İkinci Y1lında Dava Şartı Arabuluculuk Alanında Gelişmeler ve Öneriler

yasaların gözden geçirilmesi ve hatta yenilenmesi konuşulmaya başlandı. Bu Türkiye'ye has bir durum değil. Arabuluculuğa bizden çok önce başlamış çoğu ülkede de mevzuatın yenilenmesine ve güncellemeler gidildiği görülmekte, bu yöndeki ihtiyaçlar dile getirilmektedir. Örneğin bu alanda yirmi yılı geride bırakmış İtalya'da dahi yeni uyuşmazlıkları yargılama dışı çözüm kapsamına alan ve bunları mahkeme dışında gidermeye yönelik Avrupa Direktifleri ile uyum sağlayacak yasa değişiklikleri yapılmaktadır (Brouni, 2018: 171).

Biz de bu çalışmamızda, mevzuat yenileme çalışmalarının sürdüğü bugünlerde, sürecin yürütülmesine ilişkin bazı hususlara dikkat çekmek istiyoruz.

Çalışma yaşamını ilgilendiren mevzuatın yenilenmesine ilişkin yasa çalışmalarında sosyal taraflara danışmak ve fikir almak, Türkiye'de yıllardan beri sürdürülen önemli bir uygulamadır. Gerek ulusal gerek uluslararası düzeyde başvurulan bu yöntem, iş hukukuna ve sosyal güvenlik hukukuna çok önemli kazanımlar getirmiştir. Bu yöntemin, konunun paydaşlarına söz hakkı tanınması yanında, sorunların tüm yönleriyle ortaya konulabilmesine güçlü katkı sağladığı, sosyal taraflarca da kabul edilmektedir. Böylelikle, yasa çıkmadan, yasanın muhataplarının konuya yaklaşımları tespit edilebilmekte, olası sorunlar baştan görülebilmekte ve nihayetinde tarafları rahatlatacak en akılcı çözümlere ulaşılabilmesi kolaylaşmaktadır.

$\mathrm{Bu}$ açıdan bakıldığında, ilk yasalaşma döneminde, yani dava şartı arabuluculuğun ortaya çıkış aşamasında, konunun gerçek muhatapları durumundaki işçi ve işverenler arasında, olması gereken düzeyde güçlü bir uzlaşma sağlanamamıştır. Konuya ilişkin olarak, sosyal taraflar yeterince bir araya gelememiş, arabuluculuğun çalışma yaşamında yaratacağı etki etraflıca ele alınamamıştır. Bu da çok önceden tespit edilerek çözüme kavuşturulabilecek sorunların giderilmesine ve sisteme olan güvenin gelişmesine engel olmuştur.

Uygulamada hâlâ, hangi konuların dava şartı arabuluculuğa konu olması gerekeceği ya da bir konunun bu kapsama girip girmediği tartışmalara neden olmaktadır. Bu noktada sorunun çözümü için açık düzenlemeler ihtiyaç duyulmaktadır. Öğretide, zorunlu arabuluculuğa tâbi uyuşmazlıkların genel ölçüsü konulduğu halde, kod halinde ya da örnekleme suretiyle sayılmadığı belirtilerek, bu noktanın bürokratlar tarafından belirlenmesi eleştirilmektedir bunun hak arama hakkına zarar vereceği dile getirilmektedir (Ekmekçi/Özekes/Atalı, 2018: 186 vd.).

Sözü edilen sorunlar dikkate alındığında, mevzuatı yenileme sürecinde, geniş katılımlı bir çalışma ortamının tesisi yaşamsal nitelik arz etmektedir. İşçi, işveren ve memur örgütleri, odalar, borsalar ve arabuluculuk hizmetine taraf olabilecek her tür sivil toplum kuruluşunun katılımına imkân sağlayacak bir çalışma ortamı yaratılmalıdır. Acelecilik sebebiyle geçmişte atılan yanlış ya da eksik adımları düzeltmek ve yeni yanlışlıklara neden olmamak için daha sağlıklı bir çalışma programı ile hazırlıklar zamana yayılmalıdır. Hiç şüphesiz ki bu noktada Adalet Bakanlığı kadar, konuya taraf olabilecek tüm kurum, kuruluş ve örgütlerin de titizlikle çalışmalara katkı vermesi gerekmektedir. Konunun her cepheden sağlıklı, özenli, vizyonlu, hukuksal dayanakları olan ve sağduyulu katkıya ihtiyacı bulunmaktadır. Aksi halde sorunları giderebilmek mümkün görünmemektedir.

\section{III- EĞİTIM}

Arabuluculuk, hukuk fakültesi mezunlarının mezun olduktan sonra uzun yıllar alışık olmadıkları bir ihtiyacı, eğitim ihtiyacını ortaya çıkarmıştır. Gerçekten de hukuk 
fakültelerinin ağır eğitiminden başarıyla çıkan çoğu hukukçu, mesleklerini, almış oldukları bu temel eğitime ekledikleri tecrübelerle sürdürmektedir. Çoğu hukukçu, önlerindeki mesleki problemi çözmeye yönelik olanın dışında bir yenilenmeyi gerekli görmemekte, kütüphanelerini bile güncellememektedir. Fakültede aldıkları bilgileri, sadece mevzuat ve içtihat değişiklikleri ile yenilemeye çalışmaktadır. İşin ilginç tarafı bu da yeterli olabilmektedir.

Arabuluculuk, bu yaşam şekline önemli bir darbe vurarak, eğitimi hukuk meslek grubuna yeniden hatırlatmıştır. Her ne kadar bu ihtiyacın temelinde, arabuluculuğun ihtiyaç duyduğu farklı disiplinlere ilişkin bilgilerin hukuk fakültelerinde verilmiyor olması yatsa da uzmanlık eğitimi bağlamında eski bilgilerin güncellenmesi bu alanda çok büyük bir adım olmuştur.

Gerçekten de çeşitli ülkelerde hukukçular dışında, bu konuda farklı disiplinlerde eğitim görmüş uzman kişilerin de arabuluculuk hizmetini sunabiliyor olmaları, arabuluculuk hizmeti sunacak kişilerin bir eğitime ihtiyaç duyacağını açıkça ortaya koymaktadır (Kaminskiene, 2018: 27) ${ }^{1}$. Özellikle ülkemizde arabuluculuğun sadece hukukçulara hasredilmiş olması ve hizmetin başka bilimsel yeterliklere de ihtiyaç duyması, hukukçuların kendilerine uzak bu disiplinlere de hâkimiyetini ve dolayısıyla bu alanlarda da eğitim görmelerini zaruri kılmaktadır. Hukukçu olsun olmasın, arabuluculuk, günümüzde başlı başına bir ihtisas alanı ve meslek haline gelmiştir. İletişim teknikleri, müzakere yöntemleri, yazışma usulleri, optimal sonuca odaklı çalışma şekilleri bir yana, kişisel davranışlara yön veren psikoloji ve sosyoloji alanındaki bilgi ihtiyacı, bu hizmeti sunanlar için eğitimi yaşamsal hale getirmiştir.

Eğitim zarureti hukukçuların bir kısmını mutlu etse de ekseriyet bunu külfet olarak görmüştür. Daha ilginci bu bakış açısı, kimi eğitim kurumlarına da sirayet etmiştir. Yani eğitim kurumu bile eğitimi bir angarya olarak algılamıştır. Bu sebeple arabuluculuk eğitimi, tamamlanması gereken bir prosedür, belge alınması gereken bir sosyal etkinlik, karşılanması ve asgari tutulması gereken bir masraf ve dahası sisteme olan saygıyı örseleyen bir ara koşul olarak görülmeye başlanmıştır. Bugüne kadarki eğitimlerin büyük çoğunluğunun oluşturduğu bu tablo, uzmanlık ve yenileme eğitimlerine yönelik motivasyonu da olumsuz etkilemektedir. Eğitimin, bu eğitim alanında bir iş garantisi getirme beklentisi dışında neredeyse hiçbir cazibesi görünmemektedir. Gereken eğitimi istenen düzeyde almayan çoğu kişi, eğitimden bir yarar sağlayacağını düşünmemektedir. Bu bakış açısı, Bakanlıkça haklı olarak açılması düşünülen ve akredite eğitim kurumlarınca yürütülmesi planlanan hemen her eğitim programına tepki gösterilmesine neden olmaktadır. Hazırlanan eğitim programlarını özenle icra eden ciddi eğitim kuruluşları, sundukları eğitim düzeyi ile bu anlayışı bir ölçüde değiştirmiş olsa da eğitim hâlâ çoğu kişi için bir prosedür olarak görülmektedir.

Türkiye'de hukukçu yetiştiren çok sayıda hukuk fakültesi bulunmaktadır. Bu fakültelerin bünyesinde yer alan öğrenci ve öğretim üyesi düzeyi kadar, eğitim sistemi ve kalitesinde de ciddi farklılıklar gözlenmektedir. Söz konusu fakültelerde yürütülen hukuk eğitiminde gerek nitelik ve gerek nicelik bakımından arzu edilir düzeyde bir standardın oluşturulamaması, doğal olarak arabuluculuk yapacak hukukçuların hukuk bilgisi düzeylerini oldukça farklılaştırmaktadır.

Ülkemizde görev yapan arabulucuların bir kısmının yeterli hukuk bilgisine sahip olmamasına bir de arabuluculuk için ihtiyaç duyulan diğer disiplinlerdeki bilgi eksiklikleri eklendiğinde, arabuluculuk hizmet kalitesi zayıflamaktadır. Gereken düzeye ulaşmamış arabulucuların söz konusu teknik yetersizliklerine, kişisel gelişim ve kültürel birikim eksiklikleri de ilave edildiğinde, sunabilecekleri arabuluculuk hizmet kalitesi oldukça düşmektedir. Bu da onların

1 Arabuluculuk yetkisini hakimlerin de kullanabildiği Litvanya'da, Arabulucuların \%81'i, hakimlik dişı mesleklerdendir. Bunların içinde avukatlar dışında psikolog ve sosyal hizmet uzmanları da bulunmaktadır. Hatta bazı cezai olaylarda nadiren de olsa arabuluculuk için Denetim Serbesti birimine başvurulduğunda, polis memurları ve savcılar da arabuluculuk yapabilmektedir. 
İkinci Y1lında Dava Şartı Arabuluculuk Alanında Gelişmeler ve Öneriler

arabuluculuk adı altında sundukları hizmeti hızla başka bir mecraya sürüklemektedir. Arabulucuların donanım yetersizliği, sistemin ihtiyaç duyduğu vasıflara sahip olmamaları, dahası, etik ilkeleri ihlal ederek ${ }^{2}$, bu eksiklerini gidermeye çalışmamaları, sunmaları gereken hizmetin tarafların çözümüne odaklı yapısını bozmaktadır.

Arabuluculuk her ne kadar yargılama olmasa da arabulucu her ne kadar yargıç değilse de arabulucunun her açıdan yüksek donanıma sahip olması, sistemin işlerliği için büyük önem taşımaktadır. Zayıf, donanımsız ve eksik eğitimli bir arabulucu, sisteme katkıdan çok zarar vermektedir.

Ülkelere göre farklılık taşıyor olsa $\mathrm{da}^{3}$ Türk arabuluculuk sisteminde arabulucunun öneri getirebiliyor olması, işaret ettiğimiz bu donanımı daha da yaşamsal kılmaktadır ${ }^{4}$ (6325 sk.15/7). Zira zaman içinde belki daha da genişletilmesi düşünülecek olan çözüm önerisi getirebilme seçeneğine sahip bir arabulucunun, önündeki soruna son derece vakıf olması zaruri görünmektedir. Nitekim öğretide arabulucunun söz konusu katkısını artırmaya yönelik görüşler de ileri sürülmektedir (Erdoğan/Erzurumlu, 2016: 51) .

Halen sınırlı bir uzmanlık alanında yürütülen uzman arabuluculuğun zaman içinde çeşitlenmesi ve çoğalması, söz konusu eğitim eksikliğinin yaratacağı zararı daha da artıracaktır. Örneğin Letonya'da şu anda görev yapan arabulucular arasında, kendi dilleri dışında, İngilizce, Rusça ve İspanyolca arabuluculuk yapabilenler de bulunmaktadır. Bu yetkinlikleri onlara, sınır aşan uyuşmazlıklarda yabancı arabulucularla birlikte çalışabilme imkân sağlanmıştır (Petersone, 2018: 89). İtalya'da ise şu anda ticari ilişkiler ve iş hukuku dışında, finans, şirketler hukuku, bankacılık, sigorta, aile, çevre ve ceza hukuku alanlarında arabuluculuk yürütülmektedir (Brouni, 2018: 171).

Bireysel yürütülen bir faaliyet ve taraflarla yüz yüze icra edilen bir meslek olması sebebiyle, arabulucuların her açıdan yeterli donanıma sahip olması, hizmet kalitesine doğrudan etki etmekte, sistemin saygınlığını ve güvenilirliğini artırmaktadır.

Bu sebeplerle eğitim programları kadar eğitici kuruluşların akreditasyonunda da büyük özen gösterilmelidir. Zira arabuluculuğun olması gerekenden daha hızlı sistemin parçası haline getirilmesi, arabuluculuk yapmak isteyen hukukçuları hazırlıksız yakalamıştır. Bu sebeple aceleyle oluşturulan eğitimler, gerek bu eğitimleri veren kurumların ihtiyaç duyulan bilgi ve personel birikimine sahip olmaması, gerek eğitimin arabulucu adaylarınca önemsenmemesi sebepleriyle yetersiz kalmıştır. Birinci yılda yaşanan bu sorun, ikinci yılda da artarak sürmektedir. Ders saatlerinin artırılmış olması, bu saatlerin verimliliği ve bilimsel düzeyi artmadıkça arzu edilen sonucu veremeyecektir.

\footnotetext{
${ }^{2}$ Arabuluculuk etik ilkelerine göre arabulucu, somut uyuşmazlıkta gerekli olan mesleki yeterliliği haiz değil ve tarafların makul beklentilerini karşılayamayacak durumdaysa, arabuluculuk teklifini reddetmeli ve hangi aşamada olursa olsun arabuluculuktan çekilmelidir. Arabulucu, mesleki yeterliliğinden ve gelişiminden sorumludur. Bu anlamda kendi mesleki bilgi ve becerilerinin sınırlarının farkında olmalıdır. Arabulucu, gerek mesleki yeterliliğinin artırılması gerekse mesleki gelişimin sağlanması için, yenileme eğitimi başta olmak üzere, arabuluculukla ilgili her türlü bilimsel ve mesleki çalışmalara katılmalıdır (m.7/1, 2).

3 Alman hukukunda taraflar arasındaki uyuşmazlığın giderilmesine yardımcı olan kişinin çözüm önerisi sunup sunmamasına göre ikili bir ayrım yapılmakta ve çözüm önerisinin getirildiği halde uzlaştırmadan (schlichtung); Çözüm önerisi sunulmaksızın yalnızca tarafların aralarındaki uyuşmazlığı çözüme kavuşturmaları için bir araya gelmelerine yardımcı olunması halinde ise arabuluculuktan (mediation) bahsedilmektedir. Alman hukukunda genel olarak zorunlu arabuluculuk yöntemi kabul edilmemekle birlikte birçok eyalette zorunlu uzlaştırma yönteminin kabul edildiği bilinmektedir (Erdoğan, Erzurumlu, 2016: 51).

${ }^{4} 6325$ sayılı Hukuk Uyuşmazlıklarında Arabuluculuk Kanununa göre arabulucu, tarafların çözüm üretemediklerinin ortaya çıkması hâlinde arabulucu bir çözüm önerisinde bulunabilir (m.15/7).

${ }^{5}$ Buna göre, yargılama giderleri açısından yapılacak düzenleme ile tarafların anlaşamamaları halinde arabulucunun sunduğu çözümü kabul etmeyen taraf yargılama sonunda daha aleyhe bir karar verilmesi halinde yargılama giderlerine mahkûm edilebilir.
} 
Arabuluculukta temel eğitim kadar, uzmanlık eğitimleri de büyük önem taşımaktadır. İkinci yılın sonunda görülmüştür ki sınavla tamamlanmayan eğitimler, sosyal faaliyet düzeyini geçememektedir. Sadece katılımla edinilen uzmanlığın bir anlamı yoktur. Zira iş hukuku uzmanı olmayan arabulucu kalmamıştır. Kısa süreli bir eğitime katılım sonrası uzman unvanına sahip olunması, her ne kadar bu alana yıllarını vermiş gerçek uzmanları rencide etse de asıl tehlike bundan çok daha büyüktür. Piyasa bilmektedir ki uzmanlık unvanını almak çok kolaydır. Dolayısıyla aslında uzmanlık yoktur. Hatta herkes uzmandır. Yani uzmanlığın ayırıcılığı kalmamıştır. O zaman uzmanlığa neden gerek vardır. Herkes uzmansa, uzmanlık ayırıcı ölçüt haline gelemez. Bu durum arabuluculuğun ciddiyetine çok büyük zarar vermektedir. Uzman arabuluculuk sıfatı ya hızla kaldırılmalı ya da uzmanlığın ayırıcı ölçüt olabilmesini sağlayacak önlemler alınmalıdır.

Arabuluculuk eğitimlerinde gerek temel gerek uzmanlık düzeyinde bir müfredata acilen ihtiyaç vardır. Bu müfredatın içeriği, arabuluculuk bilgi birikimi ile paralel gelişecektir. Ancak buna bir noktadan başlanmalı ve aday arabulucuların çalışacakları, sınava girecekleri içerik netleştirilmelidir. Müfredatın içeriğinde muğlak, kişiye göre değişebilen, aşırı soyut, birbiriyle çelişen, anlaşılmaz bilgilere yer verilmemelidir. Bu aşamada müfredatın sınırlı olmasından korkulmamalıdır. Zira Türk arabuluculuk sistemin çok genç olması, özgün bilgi birikimine sahip olmasını sınırlamaktadır. Kaygı duyulması gereken müfredatın anlaşılmaz, açıklanamaz olmasıdır. Bu hem eğitimi hem de sınavları tartışmaya açmakta, sisteme duyulması gereken güveni sarsmaktadır.

Ciddi yürütülmesi koşuluyla uzmanlık, arabuluculuk için yararlı görülebilir. Ancak uzmanlık alanları daraltılmalı ve arabuluculuk alanında duyulan ihtiyaca göre güncellenmelidir. İş hukuku, ticaret hukuku gibi genel uzmanlık alanları yerine, arabuluculuk hizmetinde ihtisasın katkı sağlayacağı alanlar belirlenmelidir. Bu gibi durumlarda anılan uzmanlık alanlarına ilişkin arabuluculuk, sadece bu alanda uzmanlık eğitimi almış arabuluculara yönlendirilmelidir. Arabuluculuk yapılan konular konusunda yapılacak istatistiki tespitler sonrası bu konularda güncellemeye gidilmelidir. Yani uzmanlık göstermelik değil, amaca matuf olmalidir.

\section{IV- ARABULUCULUK BİLGİ BİRİKIMİ}

Her hukuki yapı gibi arabuluculuk yapısı da bilgi ihtiyacı içindedir. Bundan sekiz yıl öncesi ile kıyaslandığında, bugün arabuluculuk konusunda yapılan bilimsel toplantılara yönelik yoğun ilgi, bu alanda bilgiye olan ihtiyacı açıkça ortaya koymaktadır.

Ancak son iki yıl içinde iyice artan bu toplantı trafiği bile, arabuluculuğun ihtiyaç duyduğu bilgi dağarcığını oluşturmaya yetmemiştir. Zira arabuluculuk eğitim programlarında paylaşılanlar, ülkenin ve yapının sahip olduğu bilgiden çok yaşanan tecrübelerden ibarettir. Zira Türk arabuluculuk sistemi henüz özgün bilgisini oluşturamamıştır.

Kaldı ki bu bize özgü bir durum da değildir. Arabuluculuğa bizden çok daha önce geçmiş ülkeler de bile aynı sorun dile getirilmekte, tarafların arabuluculuk konusunda yeterli bilgiye sahip olmamaları, arabuluculuğun gelişmesinin önündeki önemli etkenlerden biri olarak gösterilmektedir (Kaminskiene, 2018: 32). Hatta bu nedenledir ki Letonya'da da arabulucunun tarafları arabuluculuk konusunda çok basit bir bilgilendirme yapması zorunlu tutulmuştur (Petersone, 2018: 87).

Sadece iki yıl içinde bu alanda yapılan bilimsel çalışmalar, kitap ve makaleler neredeyse büyük ölçüde birbirinin tekrarı niteliğindedir ve sistemin özgün bilgisi sayılmaya yeterli değildir. Bu nedenledir ki konuya ilişkin hem öğretide hem de yargı çevrelerinde, birbirinin tam aksi fikirler çarpışmaktadır. Bunu bir zenginlik olarak görenler olabilir ama kanımızca mevcut arabuluculuk sistemi açısından bu bir zenginliğin değil, belirsizliğin, kargaşanın göstergesidir. 
İkinci Y1lında Dava Şartı Arabuluculuk Alanında Gelişmeler ve Öneriler

Bilimsel zenginliğin oluşabilmesi için öncelikle, sistemin denenmiş ve kabul görmüş doğrulara ulaşabilmesi gerekir. Bilimsel tartışma, bu doğrular üzerinden yapılacak daha ayrıntılı analitik incelemelerin ardından gelecektir ki, uygulamada tartışılan konulara bakıldığında ona daha oldukça zaman olduğu görülmektedir. Çoğu arabulucu görüşeceği muhatabın niteliğine göre görüşme ve tebligat yöntemleri icat etmekte, müzakere yöntemleri geliştirmekte, anlaşma seçenekleri türetmektedir. Bunların hemen hepsi de bu yönde netleşmiş bilginin bulunmaması sebebiyle, arabulucular arasındaki mesleki müzakerelerle oluşturulmaktadır. Hatta bu müzakereler bile, yüzyılın sohbet mecrası internet kanallarında yazılan birkaç cümle ile gerçekleşmektedir. Fikirler, büyük ölçüde konuya ilişkin yeterli bilgi sahibi olmadan ortaya atılmakta, sihirli formül muamelesi görmektedir. İşin ilginç yanı, bu bilgilere genellikle doğru ya da yanlış bile denilememektedir. Çünkü sistemde, doğruluğu ve yanlışlı̆̆ açıklanamayacak sayısız bilgi uçuşmaktadır.

Hiç şüphesiz son iki yıldır hemen her gün ortaya çıkan onlarca yeni sorun ve yine bu sorunlara her gün önerilen yüzlerce çözüm, arabuluculuğun bu bilgi birikiminin oluşumuna hizmet edecektir. Fakat doğal olan bu sürecin işin icrasından çok sistemin oluşum sürecinde yaşanmasıdır. Aksi halde yaşananlar tecrübeden çok kargaşa ve belirsizlik olarak tarif edilebilmekte ve sistemin güvenilirliğine zarar vermektedir.

Geçtiğimiz iki yıl içinde yaşananlardan elde edilen bilgiler netleşmemiştir. Adalet Bakanlığının en kısa zamanda, bu alanda karşılaşılan sorunları tespit ederek çözüme kavuşturması ve bunu arabulucularla paylaşması gereklidir. Bu çözümlerin belirlenmesinde, doğruların tespitinde üniversitelerden mutlaka yararlanılmalıdır. Adalet Bakanlığı, salt bu çözümleri geliştirmek üzere üniversitelerle birlikte oluşturulacak bir birimi acilen hayata geçirmelidir. Arabulucuları, sanal ortamdaki fikir alışverişinden kurtarmalıdır. Bu mecralarda gezinen yalan yanlış sayısız bilgi ile yıpranan arabuluculuk hizmeti, en kısa zamanda bu bilgi kirliliğinden kurtarılmalıdır. Sistem hak ettiği ve acil ihtiyaç duyduğu doğru bilgiye, sağlıklı yollardan ulaşmalıdır. Aksi halde ortalıkta gezinen yanlış bilgilerle yürütülen arabuluculuk faaliyetlerinin, yargı ile karşı karşıya kalması içten bile değildir.

$\mathrm{Bu}$ sebeplerle hiç olmazsa bundan sonra, arabuluculuk sıfatının kazanılması, zamana yayılmalı, devletin katkısıyla desteklenen ve güçlendirilen ciddi bir eğitim programının sonrasına oturtulmalıdır. Ülkemizden çok önce arabuluculuğu benimsemiş ülkelerde de bu tür eğitim programları uygulanmaktadır (Petersone, 2018: 88-91). Bunun için geç değildir. İster yineleme ister yenileme adıyla olsun organize edilecek yeni eğitim programları ile arabulucular belli dönemlerde geri çağrılmalı, o güne kadar oluşturulan bilgi birikimi kendileri ile paylaşılmalı ve bu birikimi hakkıyla kullanıp kullanamayacaklarını ölçen ciddi sınavlara tabi tutulmalıdır. Arabulucuların kalitesi ve bilgi düzeylerini piyasanın belirlemesini beklemek uygun bir yöntem değildir. Örnekler de piyasanın bu seçiciliğe sahip olamadı̆̆ını göstermektedir.

Üniversitelerce, başta hukuk fakülteleri olmak üzere ilgili bölümlere, arabuluculuğu konu alan dersler konulmalı, lisansüstü eğitim programları oluşturulmalıdır. Teşvik edici olması için bu programları tamamlayanlara, mesleki sınav ve eğitimlerde kolaylık sağlanmalıdır. Üniversitelerin senatolarının alacağı kararlarla, yükseköğretim kurumlarının önlisans, lisans ve lisansüstü düzeyindeki diploma programlarına kayıtlı öğrencilerin önlisans, lisans, yüksek lisans veya doktora diploması alabilmeleri için bu alandaki dersleri başarı ile tamamlamaları gerektiği kabul edilmelidir.

İlk ve orta öğretim eğitim programlarına, akran arabuluculuğu ve genel anlamda arabuluculuk uygulamasını konu alan sürükleyici dersler eklenmelidir. Bu derslerin yürütülmesinde arabuluculardan da yararlanılmalıdır. 


\section{V- ARABULUCULUK STAJ EĞİTIMI}

Arabuluculuk, teorik bilgi kadar hatta ondan daha da önemlisi uygulama becerisine ihtiyaç göstermektedir. Bugüne kadar geçen süreçte görülmüştür ki arabuluculuk faaliyetlerinin önemli bir kısmında, arabuluculuk eğitiminin gerekleri tam olarak yerine getirilememektedir. Bunda çok değişik unsurlar etki olabilir. İnsanımızın kendine has özellikleri, uzlaşma kültüründeki eksiklik, medeni ilişki kurma sorunları, pazarlık alışkanlığı, husumetçi yaklaşım, alternatifle tehdit alışkanlığı gibi taraf sorunları kadar, arabulucuların tecrübe eksiklikleri de önemli bir unsur oluşturmaktadır. Arabuluculuk eğitimlerinin yetersizliği kadar, uygulamalı sınavın da kaldırılmış olması, arabulucuların pratik özelliklerini geliştirmesine engel olmakta ve var olan kişilik problemlerinin tespit imkânını yok etmektedir. Dolayısıyla, uygulamada karşılaşılan, hatta Bakanlığa dahi ulaşan şikâyetler de göstermektedir ki, kişisel yapısı arabuluculuğa çok da uygun olmayan kişiler, salt sınavı kazanmış olmaları sebebiyle arabulucu olabilmektedir.

$\mathrm{Bu}$ önemli bir sorundur ve çözülmelidir. Arabuluculuk yapmak isteyenlerin, belli bir bilgi birikimi kadar, bu işi yapabilecek beşeri özelliklere de sahip olması ya da bu özelliklerini geliştirebilecek olmaları gereklidir. Bunun için mutlaka uygulama sınavına dönülmelidir. Ayrıca arabuluculuk eğitim ve sınav sürecini başarıyla tamamlayanlara, staj yükümlülüğü getirilmelidir. Arabulucu adayları, uygun arabuluculuk ortamlarında belirli bir süre staj görmeli ve hizmetin işleyişini takip etmeleri sağlanmalı, bunun yasal koşulları oluşturulmalıdır. Bu eksikliklerini mesleği icra ederken tamamlamaları beklenmemelidir.

\section{VI- ARABULUCULUK MERKEZI}

\section{A- Hukuki Düzenleme İhtiyacı}

Arabuluculuk faaliyetinin icra edilmesinde, yetkin arabulucular kadar, hizmet kalitesi de büyük önem taşımaktadır. Veriler, uygun ortamlarda gerçekleştirilen arabuluculuk faaliyetlerinin, insan doğası gereği daha başarılı olacağını göstermektedir. Bu sebeple ülkemizde de bir kısım arabulucular, anılan hizmeti kaliteli sunma adına "merkez" adı altında yapilanmalara gitmektedir.

Bu merkezler, uygun müzakere salonları ile hem arabulucunun faaliyetini kolaylaştırmakta hem de tarafları daha konforlu bir ortamda bir araya getirmeye gayret etmektedir. Ancak halihazırda bu merkezlerin kuruluş ve işleyişi konusunda asgari standartları belirleyen bir düzenleme bulunmamaktadır.

Merkezlerle ilgili hukuki bir düzenlemenin bulunmaması, günümüzde merkez adı altında yürütülen arabuluculuk faaliyetlerinde bir kuralsızlaşma yaratmıştır. Merkezlerin kuruluşu ve bu isim altında arabuluculuk faaliyeti yapılması, gereğinden fazla kolaylaşmış görünmektedir.

Bu kuralsızlaşmanın bir başka sonucu da dava şartı arabuluculukta kendini göstermiştir. Uygulamada, iş uyuşmazlıklarındaki dava şartı arabuluculukta taraf durumunda olan kimi kuruluşların, arabuluculuk merkezi adı altında arabuluculuk faaliyetini organize ettikleri, belirli arabulucuları da bu yapı içinde çalıştırdıkları sıklıkla dile getirilmektedir. Oysa arabuluculuk hizmeti sunacak bu tür birim ve merkezlerin işin doğası gereği arabulucular tarafından kurulması gerekir. Arabulucular tarafsız olmalıdır ve bu nedenle böyle önemli bir görevi icra etmesi beklenen söz konusu yapıların organizasyonu belirli koşullara bağlanmalıdır. $\mathrm{Bu}$ durum hizmet kalitesinin artırılması yanında, arabulucunun tarafsız olduğunu göstermesine de katkı sağlayacaktır. 
İkinci Y1lında Dava Şartı Arabuluculuk Alanında Gelişmeler ve Öneriler

Halen arabuluculuk merkezleri, ilgili mevzuatta düzenlenmiş değildir. O sebeple önce merkezlerin hukuki yapısı, sonra da akreditasyon koşulları belirlenmelidir. Uygulamada sıkça dile getirilen ancak bize göre arabuluculuk hizmetine çok da uygun olmayan şirket gibi ticari bir yapı yerine, kanunla kurulmuş özgün bir tüzel kişiliğin tesisinin çok daha isabetli olacağı kanısındayız.

Ayrıca İtalya'da olduğu gibi bu merkezlerin takip edilebileceği halka açık bir sicilin Bakanlık tarafından tutulması da yararlı olacaktır (Brouni, 2018: 75). Dahası bu merkezlere akreditasyonu verecek bağımsız bir kurumun oluşturulması da önem taşımaktadır. $\mathrm{Bu}$ kurulda Adalet Bakanlığı ve Maliye Bakanlığı mutlaka temsil edilmelidir. Kamusal karakteri olacak ve aşağıda da değineceğim bu bağımsız kurul, tıpkı Enerji Piyasası Düzenleme Kurumu (EPDK), Bankacılık Düzenleme ve Denetleme Kurumu (BDDK), Sermaye Piyasası Kurumu (SPK) gibi organize edilerek yetkilendirilmelidir. Kurulun üyeleri, görev yetki ve sorumlulukları yasayla düzenlenmelidir.

\section{B- Arabuluculukta Mesleki Faaliyet ve Hizmet Sunumu Ayrımı}

Kanımızca arabuluculuk hizmeti, arabulucu tarafindan bireysel olarak sunulan "arabuluculuk mesleki faaliyeti" ve "arabuluculuk hizmet sunumu" olarak ikiye ayrilabilir.

Buna göre “Arabuluculuk mesleki faaliyeti” ilgili yasa ve yönetmeliklerde belirtilen usul ve esaslara uygun, etik kuralları gözeten ve arabulucular tarafindan sunulan hukuki bir içeriğe sahip bireysel arabuluculuk faaliyetini ifade etmelidir.

"Arabuluculuk hizmet sunumu" ise arabuluculuk faaliyetinin gerektirdiği, ikincil faaliyetleri ifade etmelidir. Bunlar arabuluculuk için uygun bir çalışma ortam hazırlanması ile başlayan, başvuran taraflara hukuki danışmanlık, arabuluculuk oturumları için avukatlık hizmeti sunmak, hesap raporu hazırlamak gibi teknik hizmetlerle devam eden, hatta arabuluculara nitelikli akademik ihtisas eğitimi vermeye kadar uzanabilecek bir dizi ikincil hizmeti içermelidir.

Hem arabuluculuk mesleki faaliyeti hem de arabuluculuk hizmet sunumu, kaliteli bir arabuluculuk hizmetinin ayrılmaz parçalarıdır. Ancak unutulmamalıdır ki "arabuluculuk mesleki faaliyeti", bu hizmetin "arabuluculuk hizmet sunumu" ayağından farklı olarak etik kurallara tabidir.

Gerçekten de yukarıda da dile getirdiğimiz gibi arabuluculuk mesleki faaliyetinde arabulucu, süreç boyunca taraflara eşit davranma ve onların gereksinimleri doğrultusunda adil olma ilkelerini gözetmekle yükümlüdür. Taraflar bu süreçte kendi kararlarını kendileri vermektedirler. Kendi kararını verme hakkı, tarafların sürece başlamadan, süreç içerisinde ve sonuç aşamasında özgür ve aydınlanmış iradeleriyle, gönüllü ve baskı altında kalmadan karar vermelerini kapsar. Arabulucu, arabulucunun seçimi, sürecin yürütülmesi, sürece katılım, süreçten çekilme ve süreci sonlandırma dâhil olmak üzere, arabuluculuğun her aşamasında tarafların kendi kararlarını verme hakkını gözetmekle yükümlüdür. Hazırlık aşaması veya ilk arabuluculuk toplantısında kendisinin arabuluculuk sürecindeki rolü hakkında taraflara bilgi vermek zorundadır. Arabulucu karar verme yetkisinin kendisinde değil, taraflarda olduğu hususunu vurgulamalıdır. Hukuki uyuşmazlıkla ilgili olarak taraflara hukuki veya mesleki tavsiyelerde bulunamaz. Ancak gerekli ve uygun olduğunda aydınlanmış iradeyle seçim yapmalarına yardımcı olmak üzere uzmanlara danışmalarının önemini taraflara hatırlatmalı ve bu konuda tarafları bilgilendirmelidir. Daha yüksek bir anlaşma bedeli veya arabuluculuk ücreti sağlamak amacıyla, taraflardan herhangi birinin kendi kararını verme hakkına etki etmemelidir. Arabulucu, arabuluculuk sürecini yürütürken tarafsız olmak ve tarafsızlığını şüpheli hâle getirecek davranışlardan kaçınmak zorundadır. 
Tarafsızlık, arabulucunun taraf tutmamasını ve taraflar hakkında önyargılı olmamasını kapsar. Arabulucu ile taraflar arasında herhangi bir menfaat ilişkisi veya çatışması bulunmamalıdır. Arabulucu, taraflar ile arasında menfaat ilişkisi veya çatışması bulunduğu görünümü vermekten kaçınmalıdır. Arabulucu, görevini şahsen, özenle, makul sürede, güven içinde, tarafların etkin katılımıyla, hakkaniyete uygun, taraflara yeterli söz hakk1 vererek ve katılımcılar arasında karşılıklı saygı gösterilmesini sağlayacak biçimde yerine getirmelidir. Arabulucu, arabuluculuk süreci boyunca mesleğin gerekliliklerine uygun biçimde davranmak zorundadır. Arabulucu, kendisine ya da arabuluculuk sistemine duyulacak güven ve itibarına zarar verebilecek bir davranış içerisinde bulunamaz.

Yukarıda sadece bazılarına yer verdiğimiz etik kurallardan da anlaşılacağı üzere arabuluculuk mesleki faaliyeti, uzmanlık eğitimi almış olan tarafsız ve bağımsız bir üçüncü kişinin katılımıyla son derece dikkatli yürütülmesi gereken bir faaliyettir. Dolayısıyla dış etkilerden arındırılmış bir faaliyet olması, sistemin güvenilirliği için yaşamsal niteliktedir. Etik kurallarda belirtilen; "Arabulucu, kendisi tarafından makul koşullarda bilinebilecek ve tarafsızlığ 1 hakkında şüphe uyandırabilecek, doğmuş veya doğabilecek menfaat ilişkisi veya çatışmaları hakkında, mümkün olan en kısa sürede tarafları bilgilendirmelidir." hükmü de bu güvenin ne denli önemli olduğunu ifade etmektedir (m.4/4). Hatta yine etik kurallara göre; "Arabulucu ile taraflar arasındaki doğmuş veya doğabilecek menfaat ilişkisi veya çatışması, arabulucunun tarafsızlığına ve arabuluculuk sürecine açıkça zarar verecek nitelikteyse; arabulucu, tarafların aksi yöndeki talepleri ve anlaşmasına bakılmaksızın, arabuluculuk teklifini reddetmeli ve hangi aşamada olursa olsun arabuluculuktan çekilmelidir.” (m.4/5).

Arabuluculuk mesleki faaliyetinin bu hassas yapısını, arabuluculuk hizmet sunumundan ayırmak gerekir. Zira sistemin etik ilkelere uygunluğunun devamı, esasen arabuluculuk mesleki faaliyetinin etik yürütülmesine bağlıdır. $\mathrm{Bu}$ da anılan faaliyetin tarafsız sürdürülmesini zaruri kılar. O sebeple dava şartı arabuluculukta taraf sıfatı kazanabilecek kuruluşların, kurdukları ya da kurmayı düşündükleri arabuluculuk merkezlerinde sadece arabuluculuk hizmet sunumu ile yetinmeleri gerekir. Bunun dışında arabulucuları organize etmeleri, sadece sınırlı bir arabulucu listesi oluşturarak işçi ve işvereni bu arabuluculara yönlendirmeleri, ister istemez anılan hizmetin taraflı olabileceği yönünde kaygılar oluşturabilir. Etik kuralların 3.maddesindeki; "Arabulucunun tarafsızlığından şüphe edilmesini gerektirecek önemli hâl ve şartların varlığının söz konusu olması veya sonradan ortaya çıkması hâlinde, bu hususta tarafları bilgilendirmesine rağmen, taraflar, arabulucudan görevi üstlenmesini birlikte talep ederlerse, arabulucu bu görevi üstlenebilir veya üstlenmiş olduğu görevi sürdürebilir." hükmü, sözüne ettiğimiz kaygıyı ortadan kaldıracak nitelikte değildir (m.3/5). Zira uygulamada, bazı iş yerlerinde işçilerin işverence belirlenen arabulucuya gitmek zorunda bırakıldığı, hatta bu arabulucunun işverenin avukatı olduğu, oluşacak hukuki/etik sorunu aşmak için de bahis konusu 3.madde hükmünün kullanıldığı iddia edilmektedir. Söz konusu işverenler bu uygulamalarında, işçinin söz konusu arabulucuya işverenle birlikte rıza gösterdiğine (birlikte talep ettiklerine) dair bir belge hazırlatarak, 3.maddeyi kendi lehlerine kullanmaya çalışmaktadır. Bu durum öğretide de getirilen hükmün amacı dışında kullanılması olarak değerlendirilmekte ve eleştirilmektedir (Canbolat, 2018: 106).

Özellikle dava şartı arabuluculukta işçinin anılan bilgilendirmeye rağmen arabulucuyu reddedecek iradeyi göstermesini beklemek, çalışma yaşamı dinamikleri dikkate alındığında hayatın olağan akışıyla bağdaşmaz. O sebeple söz konusu kuruluşların çatısı altında faaliyet gösterecek arabuluculuk merkezlerinin, üyelerinin uyuşmazlıklarının çözüme kavuşturulmasında, arabulucu temin etmek yerine, arabuluculuk sürecinde üyelerine hukuki ve teknik hizmet sunmaları, onları bilgilendirmeleri, eğitmeleri, hatta arabuluculuk müzakereleri için uzman vekil sağlamaları çok daha isabetli bir hizmet olacaktır. 


\section{C- Merkezlerin Akreditasyonu}

Halen bir yasal temele oturmamış olsa da merkezlerin hukuki yapısı oluşturulurken konunun en önemli noktalarından birisi de merkezlerin yetkilendirilmesi/akreditasyonu olacaktır. Zira arabuluculuk faaliyetinin etik ilkelere uygun yürütülmesinde bu durum büyük önem arz etmektedir.

Geçtiğimiz iki yılda uygulamada karşılaşılan sorunlar ve edinilen olumlu-olumsuz tecrübeler, akreditasyonun gerekliliğini ortaya koymuştur. Dahası, yaşanan tecrübeler ister istemez, akreditasyon konusunda, evrensel olanlar yanında Türkiye'ye özgü kriterlere de ihtiyaç duyulduğunu göstermiştir. Biz de bu noktada, akreditasyon sırasında dikkat edilmesinde yarar gördüğ̈̈müz bazı noktalara yer vereceğiz.

Merkezlerin kural olarak tek şehirde faaliyet göstermesine izin verilmelidir. Şubeleşme düşünülecekse kuralları net belirlenmeli ve bu mümkün olduğu ölçüde sınırlı tutulmalıdır. Şube açma imkânı sunulacak ise, iznin verileceği merkezlerin bu alanda belirli bir süre faaliyet göstermiş olmalarına ayrıca özen gösterilmeli, böylesi önemli bir faaliyette esasın “arabuluculuk mesleki faaliyeti” olduğu düşünülerek, merkezlerin ticari bir yatırım alanına dönüşmesini engelleyecek ilkeler tespit edilmelidir.

Merkeze katılacak asgari ve azami arabulucu sayısı belirlenmelidir. Bir arabulucunun dâhil olabileceği birden fazla merkez olacak ise, buna bir sayı sınırlaması getirilmelidir. Birden fazla merkeze üyelik halinde, üyeliğin ve bu üyelikten ayrılmanın koşulları açikça düzenlenmelidir Nitekim İtalya'da arabulucuların en çok beş arabulucu sağlayıcı kuruluşa dâhil olabilmesine izin verilmektedir (Brouni, 2018: 79).

Merkezlerin sunabileceği hizmetler açıkça belirlenmeli ve bu hizmetlerin standartları oluşturulmalıdır ${ }^{6}$. Merkez kurucularının arabulucu olması sağlanmalıdır. Merkezlerde çalışan arabulucular arası görev devrine (tevkil) izin verilmemelidir.

Arabulucu ile merkez arasındaki hukuki ilişki açıkça yasal temele dayandırılarak düzenlenmelidir. Listede yer alan arabulucuların tarafsızlığını sürdüreceği unutulmamalıdır. Nitekim arabulucuları gösteren bu liste bazı yapılarda "Tarafsızlar Listesi-List of Neutrals" olarak tanımlanmaktadır ${ }^{7}$.

İhtiyari arabuluculukta merkezin taraflara yönelik ücret tarifesinin hangi esaslara göre belirlenmesi gerekeceği netleştirilmelidir. Buna paralel olarak, arabulucu ile merkez arasındaki mali ilişkinin ilkeleri de esaslara bağlanmalıdır ${ }^{8}$.

Merkez yönetiminin arabuluculuk faaliyetlerinden kaynaklanabilecek hukuki ve cezai sorumluluğu açıkça belirlenmelidir ${ }^{9}$. Yöneticilerin statüleri yetki alanları, görevleri ile merkez içindeki hiyerarşik yapı özenle tesis edilmeli ve buna bağlanan sonuçlar açıklığa kavuşturulmalıdır.

\footnotetext{
${ }^{6}$ Bu konuda World Intellectual Property Organization örneği için bkz. WIPO Mediation Rules, https://www.wipo.int/amc/en/mediation/rules/\#7a

https://www.wipo.int/amc/en/neutrals/

8 WIPO Arabuluculuk Kurallarında arabuluculuk merkezinin, arabulucunun ücretini, uyuşmazlık konusuna ya da hizmete etki edecek diğer unsurlara göre saatlik ya da günlük belirleyebileceği belirtilmiştir (WIPO Mediation Rules art.23). Yine aynı kurallara göre merkezin, arabuluculuk ücreti ve diğer arabuluculuk masrafları için peşin olarak, taraflardan eşit miktarda depozito alabileceği düzenlenmiștir. Ayrıca arabuluculuk sonunda alınan depozitodan artan varsa iade edilmekte, eksik varsa tamamlanması istenebilmektedir (WIPO Mediation Rules art.24).

9 Örneğin WIPO Arabuluculuk Kurallarına göre, kasıtlı bir kötüye kullanım olmadığı sürece arabulucu, WIPO ve Merkez, arabuluculuk kuralları uyarınca yürütülen herhangi bir arabuluculuk faaliyeti ile ilgili olarak herhangi bir eylem veya ihmalden dolayı hiçbir tarafa karşı yükümlü olmamaktadır (WIPO Mediation Rules art.26).
} 
Anılan yapıların mali denetiminin yeminli bağımsız denetim elemanlarınca yapılması sağlanmalıdır. Merkezlerin mali denetimi, akreditasyonun temel unsurlarından biri haline getirilmelidir. Denetim eksiklikleri yaptırıma bağlanmalıdır. Bu yaptırımların arasında, yetkinin süreli askıya alınması gibi özgün yaptırımlar mutlaka yer almalıdır. Yönetici, arabulucu, avukat, uzman, stajyer, sekreter gibi tüm merkez çalışanlarının görev tanımları ve sorumlulukları açıkça düzenlenmelidir. Çalışanların ve sunulan hizmetin organizasyonundan kaynaklanan sorumluluklar merkez üzerinde bırakılmalı, çalışanların da kusurları oranında şahsi sorumluluklarını sağlayacak hukuki alt yapı hazırlanmalıdır.

Merkezin faaliyet alanlarında yer alacak ise, arabuluculuk (temel, uzmanlık ve staj) eğitimlerinin verilmesi ile dava şartı arabuluculuğa yönelik doğrudan başvuru için akreditasyon koşulları ayrı ayrı belirlenmelidir. Akreditasyon süreli verilmelidir. Akreditasyonu sağlanacak hizmetler arasında zaman ve başarıya bağlı, yetkinliğin ibrazını arayan bir hiyerarşi sağlanmalıdır. Örneğin, önce arabuluculuk yapma hakkı, sonra eğitim organize edebilme yetkisi, ardından staj yaptırabilme imkânı verilmeli ve tüm bu hizmetlerdeki sıralı başarının ilgili birim tarafından tespiti halinde, son aşamada doğrudan başvuru alabilme yetkisi tanınmalıdır. Merkezlerin faaliyet sürelerinin sonundaki yetki yenileme başvurularında, akreditasyon birimi tarafından yetkinliğin sürdüğüne gösterecek ve önceden belirlenmiş kriterlerin sağlandığının tespiti halinde yetkilendirme yenilenmeli, aksi halde akreditasyon süreli olarak askıya alınmalıdır. Askıya alma süresi içinde tespit edilen eksiklikler tamamlandığında akreditasyon yenilenmelidir. Bununla birlikte merkezin faaliyeti sırasında tespit edilen aykırılıklar, telafisi mümkün olmayan nitelik taşıdığında, askıya alınma bir yaptırıma dönüştürülmeli, tekerrürü halinde akreditasyon iptali sonucu doğurabilmelidir.

Merkezlerin arabuluculuk sonrasında tahkim hizmeti sunup sunamayacağ 1 konusu da açıklığa kavuşturulmalıdır. Zira dünyada, bu hizmeti sunan merkezler de bulunmaktadır ve başvuranlara belirli koşullar altında tahkim hizmeti de verilmektedir. Bu yöntemde arabuluculuk süreci belirli koşullarla, tahkim ile devam ettirilerek çözüme ulaşılmaya çalışılmaktadır ${ }^{10}$.

Merkezlerin sunacağı hizmetlerin kalitesi hiç şüphesiz farklı düzeylerde olabilir. “Arabuluculuk mesleki faaliyetinin” bedeli tarifeye bağlı olacağ için bunun ciddi denetimi sağlanmalı, ihlali hem idari hem de ağır mali yaptırıma tabi tutulmalıdır. "Arabuluculuk hizmet sunumu" konusunda ise hizmetin sunum şeklinin ve düzeyinin, maliyeti itibariyle rekabet aracı olmasını engelleyici ilke ve tedbirler getirilmelidir.

Nihayetinde arabuluculuk merkezlerinin UYAP sistemine entegre edilmesi ve işlemlerini sadece bu sistem üzerinden yapabilmesi zorunlu kılınmalıdır. Bunun belgeleme konusunda yaşanacak olası sorunları giderecek, arabuluculara özgü seçeneklerle zenginleştirilmesi sağlanmalıdır.

\section{VII- ARABULUCU YARDIMCISI}

Arabuluculuk her ne kadar bireysel yürütülen bir faaliyet olsa da süreç içinde destekleyici nitelik taşıyan çeşitli katkılara ihtiyaç duyabilmektedir. Özellikle seri uyuşmazlıklarda ya da çok taraflı anlaşmazlıklarda konunun arabulucu tarafindan takibinde güçlükler yaşanabilmekte, bu da sürece olumsuz yansıyabilmektedir. Arabulucuların duyduğu bu destek ihtiyacı kimi zaman, sekretarya hizmetinin ötesinde, daha mesleki bir düzeye de ulaşabilmektedir.

${ }^{10}$ https://www.wipo.int/amc/en/center/faq/general.html 
İkinci Y1lında Dava Şartı Arabuluculuk Alanında Gelişmeler ve Öneriler

Arabulucuların, muhatap olacakları taraflarla görüşmeden önce hazırlık yapması, taraflar ve uyuşmazlık konularında bilgi sahibi olması son derece önemlidir. O sebeple arabulucuya bu hususlarda yardımcı olacak bir kişinin mesleki tanımın yapılmasında yarar olacağı kanisindayız.

"Arabulucu Yardımcısı" ya da "Yardımcı Arabulucu" olarak adlandırılabilecek bu kişi, süreçte arabulucunun yanında yer alacaktır. Arabulucunun ihtiyacı olan bilgi ve belgelerin toplanmasında kendisine yardımcı olabilecek, onun arabuluculuk oturumuna daha hazırlıklı girebilmesini kolaylaştıracak, konuya ilişkin bilgilerle donanmasına katkı sağlayacaktır. Kural olarak söz konusu yardımcının, arabuluculuk oturumlarında yer alması söz konusu değildir. Ancak süreç içinde taraflardan bilgi/belge alarak arabulucuya ulaştırmak durumuna kalabilecek olması, onun da gizlilik kapsamında yer almasını zorunlu kılabilir. O sebeple bu tür bir yardımcılık statüsünün tesisi ve işlevsel olabilmesi, ona uygun yasal alt yapının da oluşturulmasına bağlıdır.

Çalışma koşulları ile akreditasyonlarının ayrıntılı düzenlenmesi gereken ve ihtiyari olmasını önerdiğimiz bu yardımcının tüm iş ve işlemlerinden arabulucunun şahsen sorumlu olacağı da yasayla düzenlenmelidir.

\section{VIII- PERFORMANS DEĞERLENDIRME}

Hizmet kalitesinin artırılmasında performans değerlendirmesi büyük önem taşımaktadır. Zira hemen herkes, bu tür değerlendirmelerin sonuçlarından kaygılanarak, çalışmasını daha özenli yürütmektedir.

Kalite seviyesini yükseltmiş ve bu düzeyi muhafaza etmek isteyen çoğu sektörde: araba satış1 yapanlardan, ayakkabı satışı yapanlara; aşçılık yapanlardan, garsonluk yapanlara; otel yönetiminde çalışanlardan, oda hizmetlerinde çalışanlara; kreş öğretmenlerinden, profesörlere; laboratuvarda tahlil yapanlardan, ameliyathanede organ nakli yapanlara kadar hemen herkes performans değerlendirmesine tabi tutulmaktadır.

Performans değerlendirme çağdaş bir yöntemdir ve doğru işletildiğinde hizmet kalitesini artırdığı net olarak görülmüştür. Nitekim 4857 sayılı İş Kanunu ile kavramsal olarak da yasalarımıza girmiştir (Gerekçe, 2009: 96) ${ }^{11}$.

Performans değerlendirmesi arabulucular için de düşünülmelidir. Söz konusu değerlendirmenin koşulları ve yöntemi, sunulan hizmet kalitesinin artırılmasına yönelik olmalıdır. Arabulucuların, yasal yükümlülüklerine bağlılıkları, meslek etiğine saygıları, mesleki birikimleri, taraflarla olan ilişkileri ve sundukları hizmetin kalitesi, performansın en belirgin kriterleri olmalıdır.

Performans değerlendirmesi yönteminde mesleki faaliyetin yürütülmesini örseleyecek kriterler kullanmamalıdır. Görevlendirilen iş sayısının belirli bir oranının anlaşmayla sonuçlandırılması, örnek alınacak, gurur duyulacak, mutlu olunacak bir sonuçtur. Ama yüksek performans olarak adlandırılmamalıdır. Zira arabuluculukta sonuçlandırılan iş sayısı ile hedeflenen arabuluculuk başarısı arasında bir orantı yoktur. Bir günde 100 uyuşmazlığ 1 anlaşmazlık tutanağı hazırlayarak sonuçlandırmak kadar, aynı sürede 100 anlaşma belgesi hazırlayarak sonuçlandırmak da çok farklı anlamlandırılabilir, şüphe uyandırabilir. Zira arabuluculuk süreci sonundaki başarı sadece arabulucunun performansına bağlı değildir. Tarafların durumu, sonuç alınmasında çok daha etkilidir. $O$ sebeple performans

\footnotetext{
${ }^{11}$ İş Kanunu'nun gerekçesinde, işçinin yeterliliğinden kaynaklanan geçerli sebeplere örnek olarak verilenlerden "gösterdiği niteliklerden beklenenden daha düşük performansa sahip olma" ifadesiyle performans değerlendirmesinin feshe gerekçe olabilmesi sağlanmıştır.
} 
değerlendirmesinde, görevlendirilen uyuşmazlıklardaki anlaştırma oranı ya da anlaştıramama oranı dikkate alınmamalıdır.

Ancak uygulamada bazı arabulucuların, sadece anlaşmazlık belgesi hazırlamakla geçimini sağladığı ileri sürülmektedir. Bunların arabuluculuk hizmeti değil, "arabuluculuk aşamasını hızla geçirerek, dava açılmasını sağlama hizmeti” sundukları söylenmektedir. Söz konusu durum, performans değerlendirmesi ile denetim altına alınabilecek bir sorun değildir. $\mathrm{Bu}$ durum çok daha vahim bir tabloyu işaret etmektedir. Anılan davranışlarda bir etik ihlal söz konusudur ki buna uygulanacak yaptırım performans eksikliğinden değil, etik ihlal kaynaklı olmalıdir.

Arabuluculuk performans değerlendirmesiyle, hizmet kalitesinin artırılması hedefleneceğinden, bu hizmeti değerlendirecek kısa ve basit sorulu anketler işlevsel olabilir. Arabulucu bürosuna başvuran ilgililere bürodan verilecek anket formları ya da linkleri, onları bu alandaki değerlendirmelere sevk etmeye yeterli olabilir. Aynı şekilde her arabuluculuk hizmeti sonrası sistemin kapatılması bu tür bir anketin taraflarca doldurulmasına bağlanabilir. Söz konusu anket sonuçlarından elde edilecek veriler ise ancak bilimsel usullerle analiz edildikten sonra arabulucunun performansı değerlendirilmelidir. Bunlardan elde edilen geri dönüşlerle, arabuluculuğun işlerliği artırılmalıdır.

Hiç şüphesiz bu tür performans değerlendirme sonuçları ilk etapta moral bozucu sonuçlar doğurabilir. Ancak bu durum motivasyonu bozmaktan ziyade, motivasyon artırmaya yönelik olarak kullanılmalıdır. Süreç içindeki eksikliklerin tespiti bir avantaja dönüştürülerek, arabuluculara bu eksiklikleri giderebilecek katkıların sağlanmasına özen gösterilmelidir. Arabulucular eksiklikleri ve hataları ile yalnız bırakılmamalıdır.

\section{IX- DÜZENLEYİCI VE DENETLEYİCI ÜST KURUM}

Arabuluculukta geçen son iki yıl, sistemin son derece büyümeye uygun bir potansiyel taşıdığını göstermişse de doğru yönetilmediğinde son derece önemli sorunlara yol açabileceğini de ortaya koymuştur.

Arabuluculuk ortaya çıkışından bugüne Adalet Bakanlığımız tarafından organize edilmektedir. Ancak bu kısa süre içinde bile ulaştı̆̆ 1 boyut, yarattığı sorunlar, doğurduğu ekonomik piyasa ve arabulucuların kurduğu örgütsel yapılar ile merkezler, arabuluculuk yapısının yönetimini oldukça güçleştirmiş görünmektedir. Halen Adalet Bakanlığının bu yapıya müdahale alanlarının sınırlı olması, hızla büyüyen bu yapının zaman içinde ulaşacağı boyutuyla yönetiminin oldukça güçleşeceğini göstermektedir.

Adalet Bakanlığı, yargı organları üzerindeki iş yükünü azaltmak için başlattığı bu uygulama ile mahkemelerin işlerini hafifletmeyi başarsa da her geçen gün kendi üzerindeki iş yükü artmaktadir.

Arabuluculuk sektörü, arabulucularıyla, yardımcı destek elemanlarıyla, merkezleriyle, dernekleriyle, eğitim kurumlarıyla, denetim ihtiyacıyla ve her geçen büyüyen ekonomisiyle bağımsız bir üst kurum tarafından yönetilme ihtiyacına doğru ilerlemektedir. Yakın bir gelecekte, sistemin iç dinamikleri ve ihtiyaçları, sadece bu işe özgülenmiş bir kurumun varlığını gerektirecek gibi görünmektedir.

Kamusal nitelik taşıyacak ve "Arabuluculuk Üst Kurumu” olarak adlandırılabilecek bu kurum, Türkiye'nin yabancı olduğu bir yapı değildir ve bir ilk olmayacaktır. Bu kurum da yukarıda dile getirdiğimiz üzere tıpkı EPDK, BDDK ya da SPK gibi organize edilerek yetkilendirilebilir. Üyeleri, görev yetki ve sorumlulukları yasayla düzenlenebilir. 
İkinci Yılında Dava Şartı Arabuluculuk Alanında Gelişmeler ve Öneriler

Üyelerinin arabulucular arasından belirlenmesinde yarar gördüğümüz bu kurumda, Adalet Bakanlığı ve Maliye Bakanlığı mutlaka temsil edilmelidir. Zira arabuluculuk yargısal bir hizmet olmasa da ilam niteliğinde belge oluşturabilme kabiliyetine sahiptir ve dava şartı arabuluculuk hizmeti, kamu mali kaynakları ile desteklenmektedir. Bir süre daha Adalet Bakanlığı tarafından sürdürülebilecek olsa da önemli bir yapısal adım atılabilmesi için "Arabuluculuk Üst Kurumu" şeklinde bir yapılanmaya geçilmesi, bireysel ve kurumsal akreditasyonun, bireysel ve kurumsal denetim ve yaptırımların bu kurul tarafindan yürütülmesi seçeneği de düşünülmelidir.

\section{X- IDARE VE KAMU GÖREVLILERI}

İdarenin taraf olduğu arabuluculuk işlemlerinde sonuç alınabilmesi için daha organize bir yap1 kurulması sağlanmalıdır. Her kurum için kurulacak yapı net belirlenmelidir. Kurul üyelerinin sorumlu olma kaygısıyla atıl kalmalarını engelleyecek, güven veren adımlar yasayla düzenlenmelidir.

Kamu kurumları arabuluculuk birimleri oluşturmalıdır. Kendi kurumlarında arabuluculuk unvanına sahip arabuluculardan bu kurullarda yararlanılmalıdır. Kurulda ya da arabuluculuk süreçlerinde görev yapan kamu görevlilerinin, gerçek görevleri ile bu görevleri arasındaki ilişki açıkça düzenlenmeli, çalışma süreleri ve arabuluculuk faaliyetlerindeki katkılarına yönelik ücretlendirme mevzuatla açıklığa kavuşturulmalıdır.

Kamu çalışanlarının arabuluculuk yapabilme imkânları sürdürülmelidir. Ancak söz konusu faaliyetin, kamu görevlisinin görevini aksatmaması ve yürüttükleri işleri ile bağdaşır nitelikte olması, en temel ilke kabul edilmelidir. O sebeple kamu görevlilerinin görevleri ile bağdaşabilmesi halinde ve görevlerini aksatmamak koşuluyla bu faaliyetlerini yürütebilmeme esasları, yasayla açıkça düzenlenmelidir. Bu alanda kamu kurumları arasında bir eşgüdüm ve standart sağlanmalıdır.

\section{XI- ÜCRETLENDİRME}

Arabuluculuğun mahkemelerin iş yükünü hafifletme dişındaki en temel işlevlerinden birinin de halen oldukça yüksek olan yargılama maliyetlerini düşürmek olduğu kabul edilmektedir. Arabuluculuk sistemine sahip hemen her ülke bu noktayı, özellikle iş uyuşmazlıklarındaki arabuluculuğun belirgin özelliği olarak vurgulamaktadır (Kaminskiene, 2018: 32; Peterson. 2018: 93). Gerçekten de sistemin düzgün işletilmesi halinde uyuşmazlıkların arabuluculuk aşamasında giderilmesi, mahkemede çözümü ile kıyaslanamayacak ölçüde bir maliyet avantajı sağlamaktadır.

Bununla birlikte iki yıllık uygulamamızda, bu noktada da çeşitli sorunlarla karşılaşılmıştır. Uygulamada, arabuluculuk hizmeti sunduğu halde hakkını alamayan arabulucuların bulunduğu bilinmektedir. Bu sorunu çözebilmek ve arabuluculuk ücretinin tahsilindeki sorunları önleyebilmek için, arabulucu ücret makbuzunun da arabuluculuk anlaşması gibi ilam hükmünde olması ve rüçhanlı alacak kabul edilmesi için yasal düzenleme yapılabilir. Ayrıca arabuluculuk uygulamasında taraf vekillerinin de vekâlet ücreti düzenlemeleriyle teşvik edilmesi yararlı olacaktır.

Son tutanakta işçilik alacaklarının rakamsal ifadesine yer verilmemesi, sonrasında hazırlanan anlaşmada yer verilen rakamlarla örtüşmeyen standart arabuluculuk ücretlerine razı olunması ve bu anlaşmaların gizlilik koşulu sebebiyle takip edilememesi, arabuluculuk anlaşmalarını hızla dava yolunu engelleyen ibranameler olmaya sürüklemektedir. Onun ötesinde bu tür örtülü anlaşmalar, takip ve tespit edilemediği sürece devleti önemli bir vergi gelirinden de mahrum bırakmaktadır. Bu sebeple arabuluculuk anlaşmalarının ve kesilen arabuluculuk makbuzlarının da gizlilik kuralları yeniden yapılandırılarak, Adalet Bakanlığına 
sunulmasında yarar bulunmaktadır. Bu konuda Adalet Bakanlığı ve Maliye Bakanlığının hazırlayacağı bir yasal düzenlemeye ihtiyaç vardır. Böylelikle dava şartı arabuluculuğun devlet tarafından karşılanan kısmı için önemli bir kaynak yaratılacak ve daha da önemlisi bu alanda arabulucular arasında oluşan kaygıların önüne geçilerek sistemin işlerliği şeffaflaşacaktır.

Nihayetinde vergi kaçağının önlenmesi ve haksız rekabetin önüne geçilebilmesi için, arabuluculuk ücret makbuzunun son tutanak ile birlikte sisteme yüklenmesinin zorunlu kılınması ve gizlilik düzenlemelerinin de buna uygun yapılandırılması faydalı olacaktır.

\section{XII- KADROLU ARABULUCULUK SORUNU}

Arabuluculuk etik kurallarına göre, arabulucu, süreç boyunca taraflara eşit davranma ve onların gereksinimleri doğrultusunda adil olma ilkelerini gözetmekle yükümlüdür (m.1). Tarafsızlık bu alanın en temel ilkelerindendir.

Etik kurallara göre tarafsızlık, arabulucunun taraf tutmamasını ve taraflar hakkında önyargılı olmamasını kapsar. Arabulucu, taraflardan birinin kişiliğine, geçmiş̧ine, inanç ve değerlerine ve arabuluculuk sürecindeki tutum ve davranışlarına veya başka bir sebebe dayanarak taraf tutmamalı ve önyargılı davranmamalıdır. Arabuluculuk sürecini yürütürken tarafsız olmak ve tarafsızlığını şüpheli hâle getirecek davranışlardan kaçınmak zorundadır. Arabuluculuğu tarafsız bir şekilde yönetemeyecek ise arabulucu olma teklifini reddetmeli ve hangi aşamada olursa olsun arabuluculuktan çekilmelidir. Taraflarca aksi kararlaştırılmadıkça, arabuluculuk sürecini arabuluculuğa uygun tarafsız bir yerde yürütmelidir (m.3).

Yine etik kurallara göre arabulucu ile taraflar arasında herhangi bir menfaat ilişkisi veya çatışması bulunmamalıdır. Arabulucu, taraflar ile arasında menfaat ilişkisi veya çatışması bulunduğu görünümü vermekten kaçınmalıdır (m.4).

$\mathrm{Bu}$ genel ilkeler, konu iş uyuşmazlıkları olduğunda daha da önemli hale gelir. Zira iş uyuşmazlıklarında, hayati çıkarlar söz konusu olduğu için duygusallık çok daha yüksektir. İşçinin ekmek parasını ve iş yerinde saygı görmeyi yaşamsal kıldığı bir ortamda, işveren için asıl olan güvenilir personel, itibar ve ticari sır olduğunda, taraflar arasındaki ortak noktanın bulunabilmesinde arabuluculuğun en uygun yöntem olduğu kabul edilmektedir (Peterson, 2018: 94).

$\mathrm{Bu}$ koşullara ve yukarıda işaret edilen etik kurallar rağmen uygulamada, arabulucunun tarafsızlığında tereddütler yaratacak örnekler, arabulucular tarafından her geçen gün daha sık dile getirilmeye başlanmıştır (Canbolat, 2018: 106). Bazı işletmelerin çalışacakları arabulucuları belirledikleri, arabuluculuk aşmasında işçileri bu isimlere yönlendirdikleri iddiaları ve kaygıları artmıştır. Bu durum, ihtiyari arabuluculuk için doğal görülebilecek kadar basit bir konu olmaktan çıkmıştır. Kaldı ki dava şartı arabuluculuk uygulamalarında da bu yola başvurulduğu ileri sürülmektedir. Söz konusu uygulamanın yaratabileceği önemli sorunlar bulunmaktadır.

Gerçekten de iş yerindeki tüm uyuşmazlıkları aynı arabulucu ya da arabuluculara götürmek, iş̧̧inin onun tarafsızlığına olan güvenini sarsabileceği gibi arabuluculuk sistemine inancı da örseleyecek bir uygulamadır. Seri arabuluculuk faaliyetlerinde, kimi işverenlerle yasal rayicin altında arabuluculuk ücreti anlaşması yapıldığı, her geçen daha sık dile getirilmektedir. Özellikle seri arabuluculuk faaliyetlerinin ücretlendirmesinde saat esasının uygulanması, bu yöndeki manipülasyonu körüklemekte, arabulucuları karşı karşıya getirebilme tehlikesi yaratmaktadır. Oysa söz konusu faaliyet, Adalet Bakanlığının belirlediği tarifeye uygun olarak, açık, şeffaf ve doğru vergilendirilerek yürütülmelidir. Bunun takibi ilgili birimler tarafından özenle yapılmalıdır. İhlallere gereken yaptırımlar uygulanmalıdır. 


\section{SONUÇ}

Arabuluculuk ülkemizde, son sekiz yılın en çok konuşulan hukuki yapılarından biri durumundadır. Yaklaşık sekiz yıl önce hukuk sistemimize girmiş olsa da 2017 yılında dava şartı haline getirilmesiyle, gündemdeki yeri çok daha üst sıralara çıkmıştır. Arabuluculuğun iş uyuşmazlıkları gibi son derece özgün bir uyuşmazlık alanında dava şartı haline getirilmesi, sosyal taraflarda çok farklı değerlendirmelere sebep olmuştur. Sistemin işleyişini olumlu bulunlar gibi ondan şikâyet edenler de bulunmaktadır. Esasen dava şartı arabuluculuk, geride kalan iki yıl içinde çok önemli tecrübeler yaşamıştır. Bunların bir kısmı, sistemin yeniden yapılandırılması gereken taraflarını ortaya koymuştur. Bir kısmı ise, sistemin eksikliklerinin anlaşılmasına yol açmıştır. Dolayısıyla arabuluculuk, dinamik yapısıyla Türkiye'de yavaş yavaş şekil almaya başlamış görünmektedir. Belki yasanın hazırlık aşamasında yaşanması gereken tecrübenin bir bölümüne bu süreçte muhatap olmak, beklenmeyen sıkıntılara yol açsa da alınması gereken önlemlere inancı artırdığı gibi konuya ilişkin çalışmaları da hızlandırıp, güçlendirmiştir. Arabuluculuk sistemine sahip çıkan arabulucuların ve Adalet Bakanlığının çabalarının, karşılaşılan bu sorunların giderilmesine önemli katkı sağlayacağı görülmektedir. Biz de bu çalışmamızda, geride bırakılan dönemden elde edilen veriler 1şığında, ileride yapılmasında yarar gördüğ̈üüz bazı hususlara yer vermeye gayret ettik.

Bu bağlamda, mevzuatın aksayan yönlerinin gözden geçirilmesi, hatta mümkünse yeni bir yasanın hazırlanarak konuya ilişkin dağınık yapının giderilmesi yararlı olacaktır. Geride bırakılan dönemden elde edilen tecrübe, arabuluculuk eğitimlerinde de önemli sorunlar olduğunu göstermiştir. Bu sebeple eğitim programlarının, eğitici kuruluş ve eğiticilerin akreditasyonunun gözden geçirilmesi yararlı olacaktır. Eğitim programlarının oluşmasında üniversitelerle kurulacak güçlü bağlantılar, sistemin ihtiyaç duyduğu bilgi birikiminin oluşmasına katkı sağlayacaktır.

Önümüzdeki süreçte yapılması gerekenler sadece mevcut yapının gözden geçirilmesinden ibaret olmamalıdır. Arabuluculuk faaliyetinin gelişmesine ve olgunlaşmasına katkı sağlayacak yeni adımlara ihtiyaç vardır. Bu kapsamda olmak üzere arabuluculuk stajı ve arabuluculuk yardımcılığı gibi yeni pozisyonların yapılandırılmasının, performans değerlendirmesi gibi çağdaş uygulamaların yararlı olacağı kanısındayız. Aynı şekilde arabuluculuk faaliyetinin önemli bir unsuru olması beklenen arabuluculuk merkezlerinin hukuki bir statüye kavuşturulmasının da zaruri hale geldiği görülmektedir. Nihayetinde arabuluculuk faaliyetinin saygınlığını, güvenilirliğini ve etkinliğini artırmaya yönelik tedbirlerin alınması gerektiği, bu alanda oluşturulacak düzenleme ve denetleme birimlerinin faydalı olabileceği kanısındayız.

\section{Kaynakça}

Brouni, Brouni, A. (2018). Recent Developments in Mediation in Civil and Commercial Disputes in Italian Law. International Symposium on Enhancing Mediation. 6-7 December 2018. Ankara. 171-180.

Canbolat, T. (2018). İş Hukuku Bakımından Arabuluculuk, Arabuluculuğun Geliştirilmesi Uluslararası Sempozyumu. 6-7 Aralık 2018. Ankara. 95-110.

Ekmekçi, Ö., Özekes, M. ve Atalı, M. (2018). Hukuk Uyuşmazlıklarında İhtiyarî ve Zorunlu Arabuluculuk. İstanbul 2018.
Erdoğan, E. ve Erzurumlu N. (2016). Hukuk Uyuşmazlıklarında Türkiye'nin Arabuluculuk Tecrübesi ve Zorunlu Arabuluculuk Taslağı. İstanbul 2016.

Goodman, A. (2004). Basic Skills for the New Arbitrator. Rockville. 2004.

Kaminskiene, N. (2018). Mediation in Lithuanian Law and Recent Developments of Family Mediation in Lithuania. İnternational Symposium on Enhancing Mediation. 6-7 December 2018. Ankara. 23-32. 
Özbek, M. S. (2009) Alternatif Uyuşmazlık Çözümü. Ankara.

Pekcanitez, H., Atalay, O. ve Özekes, M. (2013). Medeni Usul Hukuku. Ankara.

Petersone, Z. (2018). Mediation in Latvia and Peculiarities of Mediation in Labour Disputes. International Symposium on Enhancing Mediation. 6-7 December 2018. Ankara. 79-94.

Tanrıver, S. (2011). Hukuk Uyuşmazlıkları Bağlaminda Alternatif Uyuşmazlık Çözüm Yolları ve Özellikle Arabuluculuk, Makalelerim II (2006-2010). Ankara. 3-31.

Türkiye Arabuluculuk Etik Kuralları. [www.adb.adalet.gov.tr/ Sayfalar/ Teskilat/ mevzuat/ etik_kurallar.html/ www.wipo.int/amc /en/center/faq/general.html]. 